question that delivery ought to be at once effected? The difficulty with the vectis and forceps arose from the frequent recession of the head, for, as Mr. Jones remarks, there was no impaction; and he wishes to impress upon your readers, that he could have performed an operation in little more than half an hour, which the highest authorities in the art never knew to have been done, and believe to be an impossibility. The same cause (the recession) produced great difficulty in the perforation of the head, and the extraction of the child appeared to be impeded by spasmodic contraction of the fundus and body of the uterus around it. I contend, then, that, from the general circumstances of the case, we were imperatively called upon to deliver, and that the post mortem satisfactorily accounts for the difficulty in the use of the instruments, by revealing the ruptured state of the uterus, and that the practice pursued is sanctioned by high and multiplied authority, and I do not believe that any competent judge would question it.

Harrow, February, 1846. I am, Sir, yours respectfully, Edward C. Trte.

ROYAL MEDICAL AND CHIRURGICAL SOCIETY. (THE BUST OF THE SURGICAL JANUS.)

WE have received the following note from Dr. Cursham, and readily place it in our columns. It certainly was a lucky snd well-timed accident which led to the removal of an offensive resemblance to a bad original.

To the Editor of THE LANCET.

Sir, - Will you do me the favour to state in the next number of THE LANCET,- that the removal of Mr. Lawrence's bust (along with that of Dr. Bright) was merely a temporary arrangement, until additional brackets were put up in the library, and that the Council had no knowledge whatever of this proceeding, which originated entirely with myself.

I am, Sir, your obedient servant, Grorge CuRsham,

Saville-row, March, 1846.

Hon. Sec. to the Royal Medical and Chirurgical Society.

ON REFLEX MUSCULAR ACTIONS. NOTE - FROM MR. W. ANDERSON, RUTLAND. To the Editor of THE LArcer.

Srn,-I have not the slightest desire to occupy your pages with prolonged controversy upon the reflex muscular actions; nor is it at all in accordance with my taste and habits to retort the spirit and language of the letter signed "Vindex," in your last number. I could, however, serve him in his own strain, if I did not deem the subject of too important a nature to be treated with levities such as are found in Peter Pindar. In matters of science, the employment of the poignant shafts of wit, raillery, or satire, by men pretending to a scientific character, is, to say the least, inapt and unbecoming: such weapons better become the unphilosophic. Regarding medicine as a boon from the Creator to suffering humanity, I consider that it is the duty of the members of the profession to cultivate it in a calm and dispassionate spirit of philanthropy; and how much soever it may be regretted, that doctrines now established upon the firm basis of truth (and which have immortalized the names of the founders) were opposed by ignorance, prejudice, and passion, we are not warranted in receiving any new doctrine without a full and searching investigation of its merits. If it withstand such investigation -if its truth appear ultimately in native lustre to the entrre conviction of the world, it will be the more durable, and its author's name will be deservedly handed down to posterity, associated with an imperishable fame. I revere the memory of Iarvey, Hunter, Sydenham-of Galileo and Kepler-and of others less illustrious who have advanced the cause of science- of medical science and humanity. I respect the name of I)r. Marshall Hall, but I can see no reason why his new doctrines should be encircled with the halo of sanctity with which "Vindex" would shield them from the scrutiny of the profession. Whether they be proved to be true or erroneous, Dr. Marshall Mall has nerited his wreath, by turning the attention of the profession to the inquiry of a subject most important in human physiology and pathology; but I cannot help thinking, that such intemperate zeal as is manifested in the letter of "Vindex" will do more to unset tle the new doctrine of the independent function of the spinal marrow, than all the arcuments brought against it by its opponents. He brings into the field the same intolerant spirit of dogmatical denunciation in defence of his conviction, which he would no doubt loudly deprecate, if exercised against it.

It is, indeed, a grave and serious matter to appear before an entire profession charged with ignorance of so small a.portion of the human structure as the olfactory nerve, and it was no little relief to me to find, at the conclusion, that that entire profession is included, "at one fell swoop", in a charge of gnorance also. For my own part, so obtuse are my faculties, that my ignorance cannot perceive its egregious error. I cannot, in my conscience, plead guilty to the charge, nor can I see that my accuser has substantiated it against me. I have not interfered with the anatomy of the olfactory, but $I$ am disposed to repeat, that, in viewing the function of that nerve,when I see impressions made upon its sentient extremity, followed immediately by certain muscular phenomena,-1 regard them in the relation of cause and effect, notwithstanding the intervention of a sensation.

I shall now, Sir, for the present, withdraw from this subject; but if I live, I shall return to it another day, when more fortified by facts deduced from observation, \&c. Oakham, Rutland, Feb. 1846.

W. Anderson.

** We regret that, from the crowded state of our columns, we could not conveniently publish the whole of the letter of Mr. Anderson. Confident are we that the discovery made by Dr. Marshall Hall is one of the most brilliant to be found in the records of physiology. Mr. Anderson will find the subject to be in every respect worthy of his most attentive consideration.-ED. L.

\section{A NATIONAL FACULTY OF MEDICINE.}

To the Editor of The LaNcet.

Srr,-I was very much gratified on reading your editorial remarks contained in THE LANCEN for February $28 \mathrm{th}$, concerning the formation of a Natronal Faculty of Medicine, together with the resolutions of the Council of the British Medical Association on the same subject. Both of these, if I mistake not, contain the elements of much good to the profession. Certain it is, the time has now arrived when nothing short of a National Faculty will satisfy the requirements of our body; and the sooner the British Medical Association buckles on its armour, and commences the honourable fight for it, the better.

No institution, as it appears to me, has stood its ground more faithfully in professional opinion than this, and no institution is more capable of originating a scheme of voluntary organization for this purpose. These views have not been hastily forced on my belief; for as yet I have not attached myself to any reform association whatever. I have been content to be a quiet, unobtrusive olserver of all such matters. The time, however, has now arrived when I cannot help believing, that if the profession would but rouse from its extraordinary apathy, and be more united, each part making some concessions for the general good,- no portion of it asking for too much,-a Faculty of Medicine might be formed, (say for England, as a starting point), which, by its system of representative government, its mode of conducting the education of candidates for the profession, its rewards for scientific medical improvements and discoveries, its registration of all classes of the profession, \&c. \&c., must ultimately, if not speedily, force itself on the notice of the government. The profession cannot possibly remain much longer in its present anomalous condition; something must be done, and that soon, to ameliorate it, or it will not long exist as a profession. $* * *$, The existing institutions might remain as they are. Let the College of Yhysicians grant the diploma of physician, the College of Surgeons that of surgeon,-let the surgeon who wishes to practise pharmacy in addition, apply to the Apothecaries' Cornpany,-let all these elements be for the present incorporated in a Faculty of Medicine,-let the faculty register these diplomas, and publish the list, annually, of physicians and surgeons thus entitled to practise, - let the moneys thus acquired, and by the registration of all students entering the profession, be appropriated to the cause of medical science, in granting premiums for valuable discoveries and improvements in all the departments of medical science, with the publication of an annual registration lisî, a national Pharmacopoeia, \&zc. \&c. * * * To the British Medical Association I would say, "You are the only body who ought to undertake the management of this matter;" and to the profession, and more especially to the surgeons in general practice, (really the bulk of 